\title{
The Revised Programme of Instruction, 1900-1922
}

\author{
Thomas Walsh^ \\ St Patrick's College, Dublin, Ireland
}

The focus of this article is the Revised Programme of Instruction (1900), which was devised in the final years of the nineteenth century and implemented in Irish national schools between 1900 and 1922. It begins by analysing the societal and educational context for the Revised Programme. Second, the work of the Commission on Manual and Practical Instruction, which provided the research evidence base for the introduction of the Revised Programme, is documented. This is followed by a delineation of the content of the programme, focusing in particular on the subject areas and methodologies. The impact of wider educational developments on the programme in this period is then reviewed, such as the reform of the inspectorate and teacher training. The implementation of the programme between 1900 and 1922 is then examined, highlighting successes and shortcomings in this regard. The article concludes by drawing implications for the contemporary context regarding curriculum planning and implementation.

\section{Introduction}

There were four major revisions of the national school curriculum in Ireland in the twentieth century - namely, the Revised Programme of Instruction introduced in 1900, the programme adopted in 1922 on the advent of independence, the 'New Curriculum' implemented between 1971 and 1999, and the 'Revised Curriculum' in operation since 1999. Each of these revisions was undertaken within a distinct political, economic, cultural and social context and introduced curricula that reflected the values and ideology of Irish society at that particular time. The introduction of the first three of these aforementioned curricula represented a seismic shift in content and methodology from their predecessor, which led to many challenges regarding implementation (Walsh, 2006).

The focus of this article is the Revised Programme of Instruction (1900), which was devised in the final years of the nineteenth century and implemented in Irish national schools between 1900 and 1922. First of all, the context for the introduction of the reform will be provided. Second, the work of the Commission on Manual and Practical Instruction, which provided the research evidence base for the introduction of the Revised Programme, is documented. Third, the preparation and content of the

^Centre for Early Childhood Development and Education, The Gate Lodge, St Patrick's College, Drumcondra, Dublin 9, Ireland. Email: Thomas.walsh@spd.dcu.ie 
programme will be examined. This is followed by an outline of broader changes to the education system in 1900, most notably the training of teachers and reforms to the inspectorate. An analysis of its implementation is then provided, focusing also on the modifications to the Revised Programme in 1904. Finally, an examination of both the positive aspects of the programme and the challenges faced in its implementation is advanced. The article concludes by linking this historical analysis to contemporary understandings of curriculum planning and implementation in the Irish context.

\section{Context for introducing the Revised Programme}

It is imperative to contextualise the wider societal and educational context for development in order to determine the factors that directly and indirectly impacted on educational policy and practice in the period under review. A number of factors coalesced in the late nineteenth century to catalyse a reform of the national school programme. In political terms, at the start of the twentieth century, Ireland was governed by England, with all national affairs decided at Westminster. There had been considerable agitation in Ireland at the close of the nineteenth century in relation to the agrarian situation, political independence, educational reform and cultural revival. The British policy of 'killing Home Rule with kindness' had many positive benefits for Ireland, and some of the educational developments in the period were granted in this context. The population had been in continuous decline since the Great Famine of 1845-47 and subsequent famines in the 1870s and 1880s, while emigration was endemic (Nic Ghiolla Phádraig, 1990). While education remained a valued commodity in Ireland, the widespread social problems, such as poor housing and healthcare, impacted on the priority and resources afforded to education at a national level, and reduced the ability of communities to support and finance education at a local level. The economy at this time, and indeed throughout much of the twentieth century, was largely agrarian based and highly dependent on Britain for its markets.

There was an efflorescence of Irish cultural activity at the end of the nineteenth century, most notably in relation to the Irish language and games. The Gaelic Athletic Association was established in 1884 to promote Irish sports for Irish people. The Gaelic Literary Society (1892) initiated a revival of Irish literary works and pursuits. However, it was the Gaelic League, founded in 1893, that proved the most successful in capturing the hearts and imagination of the nationalist population and which played the greatest part in the revival of the Irish language and culture. The cultural movement placed pressure on the Commissioners of National Education to include the Irish language on the school programme and to make Irish culture and heritage more distinct aspects of education, with some positive achievements in the period under review. The Catholic Church had grown in power and prestige throughout the nineteenth century and occupied a pivotal position in Irish society by 1900, most notably in its control and involvement in education. The dominant 
power it had built in the nineteenth century, whereby in 1900 education for the majority of pupils was 'parochially organised, denominationally segregated and clerically managed' (Ó Buachalla, 1988, p. 28), was vehemently guarded and entrenched in the twentieth century.

Following the establishment of the national system in 1831 under the Commissioners of National Education, an extensive network of close to 8,700 schools, accommodating in excess of 770,000 pupils, was operational nationwide at the start of the twentieth century (Dale, 1904). A system of Payment by Results was introduced in national schools in Ireland in 1872, following the Powis Commission report (Royal Commission of Inquiry into Primary Education, 1870). This introduced an annual examination of each child in the national schools, the result of which directly impacted on the teacher's salary. The system led to a narrowing of the programme to the examinable subjects, while the methodologies employed by teachers became didactic and mechanistic in an effort to teach towards the examination. The obligatory subjects were reading, writing, spelling and arithmetic for all grades, while grammar, geography, needlework for girls and agriculture for boys were added from third class onwards. While the model had positive effects on certain aspects of attainment in Irish education between 1872 and 1900, most notably in literacy and numeracy (Commissioners of National Education, 1900), there was growing disenchantment with the system at the close of the nineteenth century. A vast array of 'additional subjects' could also be taught, but as Table 1 delineates, these were not introduced on a widespread basis. Drawing and singing were the most popular subjects taught, while the remainder of the subjects rarely featured in Irish national schools. This had important implications for the attempts to implement subjects of a more manual and practical nature in schools after 1900 .

Despite the principle inherent in the Stanley Letter of 1831 of establishing a nondenominational system, schools had become de facto denominational by 1900, primarily managed by the local clergyman. The 8,700 schools were staffed by approximately 12,000 teachers but owing to difficulties in arriving at agreeable training provision for Catholic teachers until the $1880 \mathrm{~s}, 55.2 \%$ of teachers remained

Table 1. Extent to which additional subjects were being taught in national schools in 1896

\begin{tabular}{lc}
\hline Subject & No. of schools $(\%)$ \\
\hline Kindergarten & $364(4 \%)$ \\
Handicraft & $15(0.2 \%)$ \\
Drawing & $1,515(18 \%)$ \\
Cookery & $83(1 \%)$ \\
Laundry & $1(0.1 \%)$ \\
Domestic Science & $151(2 \%)$ \\
Hygiene & $28(0.3 \%)$ \\
Singing & $1,217(14 \%)$ \\
Irish & $75(1 \%)$ \\
\hline
\end{tabular}

Source: Commissioners of National Education (1897), p. 32. 
untrained in 1896 (Commission on Manual and Practical Instruction, 1898a, p. 56). One-teacher schools comprised approximately sixty per cent of schools and it was not unusual to have up to sixty pupils per class in urban areas. Despite the introduction of legislation relating to compulsory school attendance in 1892, attendance rates rested at only sixty-five per cent in 1900 (Dale, 1904, p. 53). The inspectorate had grown in tandem with the national system and by 1913, a cohort of seventy-six inspectors acted as a vital link between the schools and the Commissioners of National Education in Ireland (Vice-Regal Committee of Inquiry, 1913b, p. 129).

Given this context, the 1890s became a period of curricular reform for a number of reasons. First of all, the system of Payment by Results had been in operation since 1872 and despite its positive effects on national literacy, there was a general feeling that the system had outlived its purpose. It had resulted in a narrow range of subjects being taught in national schools, primarily of a literary nature, with little provision for other aspects such as physical or creative development. Second, through Ireland's association with England, there was an awareness of an international trend to place a greater focus on the holistic development of the child by incorporating manual and practical subjects in the school programme. Such developments had been introduced in England and Scotland in 1890 and there were calls for similar reforms in Ireland. Third, thinking at the time was informed and catalysed by wider international influences such as the New Education Movement, a collective name for a diverse array of groups united in a campaign for a reform of education (Selleck, 1968). Fourth, many of the other issues, such as teacher training and attendance legislation, which had remained contentious issues following 1831, had been resolved to some degree by the early 1890 s, allowing a focus to be placed on other qualitative aspects of education. Fifth, the physical growth of the system was nearing its end and there was an opportunity to focus on the content and quality of the education provided. Last of all, there was practically universal support from the Catholic Church and other churches, the inspectorate, the Commissioners of National Education and prominent Irish educationalists for a revision of the programme to incorporate more practical subjects. The main areas of concern related to the teaching of infants, the narrow range of subjects taught, the quality of the teaching of reading and the rigidity of teaching methodologies (Walsh, 2006, pp. 37-39). The turn of a century is always an apt time for reappraisal and for a focus on the future, and there was great optimism for progress in the twentieth century. As Coolahan (1975) proposed regarding the 1890s, 'It was as if change was in the air and it was not long until machinery was set in motion to bring it about as a reality' (p. 214).

\section{Commission on Manual and Practical Instruction (1898)}

The aforementioned contextual factors led to the establishment of the Commission on Manual and Practical Instruction, which reported in 1898 (Commission on Manual and Practical Instruction, 1898a). This was a comprehensive national and 
international investigation into the desirability of introducing more manual and practical subjects into Irish national schools, with the investigating committee comprised largely of the Commissioners of the Board of National Education. The purpose of the Commission's investigation was to determine 'how far, and in what form, manual and practical instruction should be included in the Educational System of the Primary Schools under the Board of National Education in Ireland' (Commission on Manual and Practical Instruction, 1898a, p. 5). Its terms of reference specifically addressed the necessary changes required within the existing programme to accommodate additional subjects, the training that would be necessary for teachers, and the provision of equipment and materials to support programme adaptation and change (Commission on Manual and Practical Instruction, 1898b, Appendix A, p. 6).

The Commission on Manual and Practical Instruction sat from January 1897 until July 1898 and the quality and range of the research completed and documented in this period is impressive. It held ninety-three public meetings, interviewed 186 people and visited 119 schools in Ireland, England, Scotland, Germany, Holland, Switzerland and Denmark. Witnesses were chosen from a wide array of educationalists such as teachers, managers, inspectors and training college personnel, but also included non-educationalists to ascertain the views of people working in agriculture and industry. The entire process and minutes of evidence gathered by the Commission were published in four volumes, as were special reports compiled based on visits to international jurisdictions. The methodical and comprehensive way in which the Commission conducted its work ensured the final report provided the basis and rationale for the reforms to the national school programme in 1900. As the following quote from Dr Starkie (Resident Commissioner in Ireland 1899-1921) reveals, the main thrust of the report was a call for radical reform, not the case that 'the school-coach be better horsed, but that it should be turned right round and started on a new track' (Starkie, 1911, p. 3).

Overall, the Commission on Manual and Practical Instruction concluded that the Irish system of education, with its literary bias, was in need of fundamental reform. It recommended a wider range of practical subjects, an emphasis on the infant classes, an alternative method of examining practical subjects other than individual examination, and that schools would become more interesting and enjoyable places. The final report proposed the inclusion of kindergarten, educational handwork, drawing, elementary science, cookery, laundry and domestic science, singing, drill and physical exercise in the school programme. This more than doubled the range of subjects to be taught in national schools, many of which were starting from a very low knowledge base among teachers and were not taught widely in schools at the time (see Table 1). However, it proposed that changes should be introduced 'gradually and tentatively', based on the ability of individual school contexts to implement the recommendations (Commission on Manual and Practical Instruction, 1898a, p. 4).

Despite the comprehensive nature of the report, it failed to adequately address two main issues that subsequently impacted on implementation. First of all, the issue of financing the additional subjects in the form of providing physical space, equipment 
and ongoing materials was not given sufficient attention. It was naïve to think that managers and localities would provide such resources, considering the tradition of centralised financing of, and public apathy towards, education. Second, while the provisions of the final report were radical for large schools, they were practically unrealistic in small schools, in a context where in excess of sixty per cent of schools contained one teacher in 1900. To implement the recommendations of the Commission in such a context was not feasible owing to the lack of space, expertise on the part of the teacher in all the new subjects, the wide age range and ability levels of the pupils, and the difficulty of providing or even accommodating all of the required equipment.

\section{Preparation and content of the Revised Programme of Instruction (1900)}

The Commissioners of National Education accepted and endorsed the report of the Commission on Manual and Practical Instruction and set about incorporating its recommendations into a Revised Programme of Instruction. In October 1898, a Committee of the National Board was established and it produced a skeletal draft of the programme in December 1898 (Vice-Regal Committee of Inquiry, 1913c, p. 491). This contained detailed provision to implement the recommendations of the Commission on Manual and Practical Instruction, including the introduction of the new subjects proposed, the provision of grants for equipment and the appointment of organisers to assist teachers implementing the programme.

The appointment of Dr Starkie as Resident Commissioner (and head of the Board of National Education) in spring 1899 interrupted this process, and he assumed responsibility for the drafting of the programme over the course of 1899 and early 1900. His appointment to this position was somewhat controversial at the time, as he was a man who by his own admission knew little of the national school system (ViceRegal Committee of Inquiry, 1913c). He was a formidable character and even in the early days in his position as Resident Commissioner, he managed to alienate and antagonise the key influences in the implementation of the Revised Programme, most notably the teachers, managers and inspectors. Under his tenure, the preparation of the programme was characterised by a high degree of secrecy, involving little consultation with senior inspectors, the Commissioners of National Education or the teachers who would be involved in its implementation. While earlier drafts of the programme were mediated for varying school contexts and conditions and allowed for gradual implementation, the plans for the school programme became increasingly universal and the pace at which implementation was planned accelerated (Walsh, 2006, pp. 84-91). While Dr Starkie consulted certain Commissioners of National Education, he was the principal architect of the programme. The two chief inspectors, the heads of the training colleges, the twenty-two senior inspectors and other educationalists were consulted on a draft of the programme in July 1900. The general thrust of their response was that the programme was, as stated by the chief inspectors, 'much too extensive, probably quite beyond what would be possible even 
in the most favourably conditioned National School ... and quite unattainable in the Ordinary National Schools with one or two teachers' (Downing \& Purser, 1900, p. 489). These concerns, and those of others, were largely ignored and Dr Starkie pressed ahead with introducing the programme in September 1900.

The Revised Programme of Instruction abolished the system of Payment by Results. Such a system would not have afforded the curricular freedom required for the reforms anticipated, owing to the focus on core literary subjects and the emphasis placed on preparation for annual examinations. The programme, rather than being prescriptive and didactic in nature like its predecessor, outlined the general programme that should be pursued in national schools. The fundamental nature of the changes was acknowledged, affecting both content and methodology: 'The Revised Programme not merely prescribes certain new subjects and excludes some old ones; but also involves some radical changes in the methods of instruction' (Commissioners of National Education, 1902a, p. 7).

The programme contained little of a theoretical or ideological framework and did not make reference to the evidence gathered in the Commission on Manual and Practical Instruction. From an analysis, the philosophy of the Revised Programme was child-centred and liberal relative to its predecessor. It placed an emphasis on the active participation of children in learning, rather than memorisation, and proposed a wide range of subjects of a manual and practical character to redress the previous literary bias inherent in the programme. The programme was to cater for the needs of all children by being flexible and by providing a balanced curriculum to support all aspects of development (Commissioners of National Education, 1902b, p. 68). English (with its subsets of reading, writing, spelling, grammar and composition) and arithmetic were the two compulsory subjects within the programme in all schools. Kindergarten, manual instruction, drawing, object lessons, elementary science, singing and physical drill were compulsory subjects where there were teachers qualified to teach them. In addition, cookery, laundry and needlework were to be taught to girls where teachers were qualified and equipment available. The list of additional subjects was greatly reduced to include Latin, French, mathematics, Irish and instrumental music, but these could be taught in the course of the school day as long as the core subject areas were not negatively affected.

The time afforded to the traditional subjects was four-sevenths of the teaching time, while the new subjects outlined were to occupy the remaining three-sevenths. Time was gained by reducing the requirements in certain subjects (e.g. grammar and geography), by grouping related subjects and by reducing the time allocated to subjects such as needlework. The methods of instruction in use were also to be modified, replacing the didactic with a more child-centred, heuristic approach, especially for the practical subjects (Commissioners of National Education, 1902b, p. 68). As is evident, this was a huge addition to the existing programme at the time, which had been based largely on teaching reading, writing and arithmetic.

The Revised Programme incorporated the recommendation of the Commission on Manual and Practical Instruction, including the subjects it proposed and its suggestions for allocating time to these subjects, the abolition of Payment by Results 
and the system of training teachers in the new subjects. Evidently, the Revised Programme exceeded the recommendations of the Commission, in relation both to its content and to the pace of introducing its proposals. It did not differentiate the requirements for the various types of schools whose circumstances and contexts would impact on their ability to introduce its provisions, as had been advocated by the Commission and in earlier drafts of the programme. Similar to the Commission on Manual and Practical Instruction, the Revised Programme failed adequately to address the practicalities of implementation, such as the finance for facilities and equipment and the inherent difficulty of introducing such a range of new subjects in small schools.

The Revised Programme was generally lauded by the media as a vast improvement on the 'cast-iron and red tape' characteristics of its predecessor (The Freeman's fournal, 1900, p. 2). The Irish National Teachers' Organisation (INTO) cautiously welcomed the educational philosophy underpinning the programme but noted that it was 'so overloaded with requirements as to be absolutely impracticable' (Irish Teachers' fournal, 1900, p. 4).

\section{Alterations within teacher training and the inspectorate}

In addition to the curricular changes introduced by the Revised Programme of Instruction, a number of modifications were made to the system of training teachers, to the grading and salaries of teachers, and to the inspection system. The training colleges embraced the changes to the programme by broadening the range of obligatory subjects studied to include reading, penmanship, spelling and punctuation, grammar, composition, English, geography, literature, arithmetic, theory of method, practice of teaching, needlework, drawing and book-keeping, hand and eye training, education in kindergarten principles, physical drill, elementary science, object lessons and singing. Male students also studied agriculture and an extended programme in mathematics. In addition, all students undertook one of a possible twenty-one optional subjects. There was also an increased emphasis on the science and art of teaching, with these aspects receiving greater proportions of the marks in examinations (Coolahan, 1981, p. 30). These additions put great strain on the students and staff in the colleges, resulting in a highly structured timetable and continuous examinations (Coolahan, 2005, p. 171). With such an array of subjects to cover, depth of instruction was more difficult to achieve and the teaching remained basic and practical in nature. Cramming was a feature of these conditions, leading to little time for assimilation and retrospection of the material studied.

The training colleges were correctly viewed as one avenue for the training of teachers. It is important to remember that in 1900, less than half of all teachers had any formal training, and those that had attended the training colleges were largely prepared in the core literary subjects and in the use of traditional didactic methodologies. Many of those untrained, due to age and circumstance, would never attend training colleges and even at full capacity, the colleges were not producing 
enough teachers to replace those leaving the service annually. Consequently, in a highly innovative move, a number of organisers were appointed to facilitate implementation in many of the new subjects that were largely unfamiliar to practising teachers. These organisers included foremost international experts in the field and they were employed for subjects such as elementary science, hand and eye training, drawing, vocal music, needlework, and cookery and laundry (Commissioners of National Education, 1905, p. 2). The organisers acted as peripatetic teachers providing practical demonstrations and advising teachers in schools on weekdays, while providing courses for groups of teachers in the evenings and at weekends. By 1904, approximately half of all practising teachers had attended training in singing, while two-fifths had been trained in needlework, cookery and laundry, manual instruction and elementary science by the organisers (Commissioners of National Education, 1905, pp. 3-7).

However, there were no supports in certain new subjects or in any of the existing subjects, which had changed quite radically in terms of content and methodology, while the training provided was short-term in nature. Moreover, there was an average of six organisers for each of the aforementioned subjects to assist a cohort of approximately 12,000 teachers, spread across 9,000 schools, in a context where travel and communication was difficult. From 1906, Junior Assistant Mistresses were appointed to conduct the work in the infant classes, and to assist in needlework and manual instruction within the senior classes, in schools without female teachers.

In tandem with introducing the Revised Programme, Dr Starkie also undertook the reform of the inspectorate. This involved reform at all levels of the inspectorate, and the administrative roles of the chief inspectors were now transformed into fieldwork in the schools. Dr Starkie reduced the inspection districts from sixty to twenty-five, with each district catered for by one senior inspector and two junior inspectors. This reorganisation caused immense dissatisfaction and two senior inspectors were dismissed temporarily for their hostility to the reforms in 1900 (Abstracts of the Board's Proceedings, 1900, p. 3).

Regarding teachers' salaries, this involved the replacement of individual examination by general inspection as the system of Payment by Results had been abolished. This, in effect, meant that the grading (and salary) of a teacher would be based solely on the inspector's report. Teachers were now classified into three grades, with a quota on the number in each grade and a fixed minimum and maximum salary. Therefore, promotion, regardless of ability, rested on the availability of a space in the next grade, thus in effect meaning many teachers received a 'paper promotion'. Unsurprisingly, the era was characterised by much contention and unrest, as the INTO became increasingly vocal and militant regarding teachers' rights under the new rating system. In addition, Archbishop Walsh resigned from the National Board in 1901 in protest at the new salary structures. The Dill Committee (1913) noted deficiencies in the organisation of the inspectorate, the slow rate of promotion for teachers and inadequacies in the appeals procedure, making nineteen recommendations to ameliorate the situation (Vice-Regal Committee of Inquiry into Primary Education, 1913a, pp. 50-52). 
These modifications to the inspectorate and teacher salary payments further exacerbated the sense of flux in Irish education in 1900. Not only did teachers have to contend with a radically different programme in schools and a revised system of inspection, much of their energies and attention were directed on their personal material circumstances as affected by the new rating system. This further reduced their welcome for or acceptance of the Revised Programme and occupied the energies of the INTO and individual teachers in seeking an improvement in their conditions, thus reducing their focus on the implementation of the programme provisions.

\section{Implementation of the Revised Programme of Instruction}

The Revised Programme of Instruction was introduced in national schools from September 1900. The programme represented the maximum of requirements to be attained, while managers and teachers were advised that they were under no obligation to implement it in its entirety. Progress in relation to the implementation of the subjects was mixed, depending largely on the level of resources and equipment needed for successful teaching of the subject. As Table 2 documents, there was a high level of implementation across the 8,700 schools in Ireland at the turn of the nineteenth century in subjects such as vocal music, drawing and object lessons, which required little equipment. Conversely, subjects such as cookery, kindergarten and elementary science, whose implementation was dependent on specific and expensive equipment, were introduced in a lower proportion of schools.

However, these statistics do not elaborate on the range or depth of implementation and it is probable that schools that were making minimal progress towards

Table 2. Number of schools in which core subjects were undertaken in national schools from 1899 to 1904

\begin{tabular}{lrrrrrr}
\hline & 1899 & 1900 & 1901 & 1902 & 1903 & 1904 \\
\hline Vocal music & 1,475 & 3,963 & 6,032 & 6,439 & 6,550 & 6,683 \\
Instrumental music & 180 & 31 & 324 & 333 & 358 & 306 \\
Drawing & 2,146 & 5,942 & 8,349 & 8,532 & 8,601 & 8,614 \\
Kindergarten and manual instruction & 448 & 1,293 & 1,954 & 2,656 & 2,165 & 2,138 \\
Cookery & 125 & 263 & 409 & 631 & 727 & 362 \\
French & 89 & 24 & 188 & 179 & 193 & 205 \\
Irish & 105 & 88 & 1,198 & 1,586 & 2,018 & 1,983 \\
Latin & 28 & 6 & 74 & 81 & 109 & 101 \\
Object lessons & - & $\star$ & 7,673 & 8,189 & 8,281 & 8,392 \\
Elementary science & - & $\star$ & 1,745 & 2,623 & 2,499 & 2,217 \\
Needlework & $\star \star$ & $1,700 \star \star \star$ & 5,851 & 5,985 & 6,140 & 6,207 \\
\hline
\end{tabular}

Source: Commissioners of National Education (1905), p. 53.

$\star 3,096$ schools undertook object lessons and elementary science in 1900 .

$\star \star$ No return, 172,337 pupils examined.

$\star \star \star$ Revised Programme of Needlework. 
implementation are included. However, evidence from the inspector's reports, the Dale report, the Dill Inquiry and other contemporary commentators point in the main to an improved education for children after 1900 (Walsh, 2006, pp. 121-129). This relates to a better atmosphere for learning, a greater variety of subjects being studied, and improved methods for the teaching of subjects such as reading and writing. The evidence also points to a deterioration in the standards of some of the traditional subjects, most notably arithmetic, grammar and geography. However, many commented that this disimprovement related to mechanical accuracy and memorisation, rather than in understanding and interest as advocated by the Revised Programme. The core subject of manual instruction enjoyed least popularity among parents, teachers and inspectors, and was largely perceived to be unsuited to national schools. It is arguable that the aims of this subject were misunderstood by many, focusing on the practical outcomes rather than the mental and educational processes involved. However, while the extent of implementation may have languished behind expectation, it is evident that the new subjects and methods permeated the system to some extent.

\section{Revisions to the programme (1904)}

Owing to a number of problems with implementation, the process of revising the programme began in 1902 and a number of reforms were introduced in 1904. These revisions were based on consultation with inspectors, subject organisers and teachers, and a review of the system by an English inspector, Mr F. H. Dale (Dale, 1904). Dale asserted that in general the standards achieved were lower in Irish schools but pointed out a number of deficiencies that led to this situation. These included the poor condition of schools, the proliferation of small schools, the low attendance rates and the lack of public interest in education. Dale also found that there was greater innovation in relation to the new subjects introduced, while those with the longest tradition and most familiarity were the slowest to change (Dale, 1904, p. 68).

The programme revisions involved the discontinuance of manual instruction in the senior classes. One reason proffered for this revision was the fact that 'expert teaching in the higher branches of manual instruction is not available, in the majority of the national schools' (Commissioners of National Education, 1906, p. 191). The course in arithmetic was revised owing to complaints that standards had declined and now included more concrete work and reasoning. The syllabus in cookery was altered and now applied only to fifth and sixth classes. A particular emphasis was placed on kindergarten and frequent changes of occupation were recommended with time allowances for rest and play in the infant classes. These revisions were significant considering the aim and contents of the Revised Programme, based on the recommendation of a comprehensive and unanimous report by the Commission on Manual and Practical Instruction. Notes for Teachers and specimen programmes were disseminated to assist implementation in April 1904 (Commissioners of National Education, 1906, p. 191). These outlined the new subject areas and 
provided further direction for the grouping of pupils in various sized schools - schools with three or more teachers, schools with two teachers, schools with one teacher and infant schools. While the provision of these notes in 1904 was a positive step, their unavailability for the first four years of implementation, arguably the most critical period, created a vacuum of supports for teachers endeavouring to introduce the new subjects.

Following a protracted campaign by the Gaelic League, a Bilingual Programme was introduced in 1904 for schools in Gaeltacht (Irish language speaking) and partGaeltacht areas where teachers were proficient in the language (O'Donoghue, 2000). This sought to teach subjects through the medium of Irish for pupils whose vernacular was Irish, and the goal was that all pupils would leave national school with a command of both Irish and English. Despite problems besetting the Bilingual Programme such as the lack of proficiency in the language among teachers, it grew in popularity and was introduced in 232 schools by 1920 (Commissioners of National Education, 1921, p. 8).

\section{Successes of the Revised Programme of Instruction (1900)}

The 1900 programme was successful in a number of ways and the evidence points to an improved education for pupils after 1900. It broke the curricular mould of schools that had been in operation for thirty years and breathed new life into the system in the form of a broad and varied curriculum with enlightened methodologies. It was framed within a comprehensive analysis of the education context nationally and internationally through the Commission on Manual and Practical Instruction. This was important to provide a basis and rationale for its introduction and gave insights into policy and practice in Ireland and other jurisdictions at that time. The range of subjects offered to pupils in national schools was greatly extended and enhanced, complementing the existing academic elements with an array of subjects of a more practical nature. The mix of these new practical subjects with the existing literary subjects enlivened school life and better prepared all pupils for life after schooling. The appointment of organisers to assist implementation of many of the new subjects proved to be a novel strategy for training teachers in the new content and methodologies, somewhat similar to the contemporary model operated by the Primary Curriculum Support Programme. While the number of organisers remained low relative to the number of teachers in need of support, the system provided a model for the dissemination of the programme to practising teachers throughout the country. The status and profile of infant education also increased greatly in this period. As O'Connor (1987, p. 16) stated, 'Infant training was placed at the core of the curriculum, and school life promised to be an enlightening period where children learned largely through play.'

Not only did the content of education change and broaden after 1900, but it was underpinned by an entirely new philosophy of education. The new heuristic methods of teaching placed children at the centre of the educational process and education 
was to be enjoyable and discovery-oriented in nature, envisaging the school as a pleasant environment for children. Last of all, the programme of 1900 was also radical for the vast amount of freedom afforded to teachers and managers of schools within the system. A specimen programme was offered from 1904 but at all times, teachers and managers were free to devise a scheme of work for their individual schools that fitted with local needs and requirements, subject to ratification by the local inspector or National Board. It is unfortunate that teachers and managers were not supported to a greater degree to use this facility, following a period in which teacher initiative and freedom was neither allowed nor valued.

\section{Shortcomings of the Revised Programme of Instruction (1900)}

Despite its many successes, it is important to analyse some of the factors that impacted negatively on the implementation of the programme. Dr Starkie's personality proved an impediment to the harmonious relations and goodwill needed to implement reforms between the key interested parties involved in national education. The revisions in 1900 were not widely welcomed or accepted by teachers, managers, inspectors or parents, and many remained dubious about the educational value of the reform. Teachers and inspectors were not consulted in the devising of the programme and thus they felt little ownership of the changes. It was an error not to keep such key personnel informed and instilled with a sense of ownership of the changes, as they were the means to translate the theory of the programme into a practical reality. Teachers, and the INTO, had objected to the range of new subjects introduced and expressed concerns regarding implementation (Irish Teachers' Fournal, 1900, p. 4; Irish National Teachers' Organisation, 1901, p. 20). As the Irish School Monthly (1900, p. 3) stated in relation to the programme:

here all is new and strange; the change is sudden and complete ... filled with subjects he [the teacher] knows little or nothing of, and which he must learn before he can teach. The old familiar school subjects are so altered that he hardly knows them again.

The large proportion of unqualified teachers and the lack of a systematic framework to train all teachers in the new subjects and methods resulted in many reverting to old teaching styles and focusing on the subjects they were most familiar with. Subsequent to courses that were provided, there was a lack of equipment and resources to support practical implementation (Irish Teachers' fournal, 1902, p. 4). In addition, specimen programmes and Notes for Teachers only came on stream following four years of implementation, thus leaving teachers unsupported at the most critical phase of implementation. As the programme stipulated the maximum of requirements, many teachers felt in awe and unable to enact such fundamental change within the context of their daily reality.

The radical nature of the proposed changes also impacted upon success as it did not take into account the reality of the Irish educational context at this time, nor of the religious, socio-economic or cultural complexities of the Irish situation. As 
Mr Heller, Head Organiser of Science Instruction to the Commissioners of National Education, stated in 1902:

In modern history of Education, there is probably in no country such an example of complete change both in administration and methods of instruction as has recently occurred in Ireland ... (Heller, 1902, p. 35)

The proposed level of funding envisaged by the Commissioners never fully materialised. The strain of financing the Boer War and the attempts of the British Treasury to devolve some level of financial responsibility for education to localities led to an actual reduction in funding for national education in Ireland (Hyland, 1987 , p. 21). This was particularly detrimental in the first years of implementing the programme, when additional finance was needed to support the training of teachers, the payment of organisers, the purchase of equipment and materials and additional expenses incurred by schools in adopting the programme. Responsibility for the provision of equipment and resources for the new subjects rested with the locality, and equipment and resources were not made available in many instances, while school buildings were often unsuited to the new methodologies proposed. The general public was, at best, apathetic towards education and, in general, was not prepared to finance it.

Overall, Ireland was not ready for such a radical programme transformation, given the proliferation of small schools, the high proportion of untrained teachers, the large class sizes and low attendance rates. The range of new subjects added, the new methodologies proposed for both old and new subjects and the change in the underlying philosophy of education proved overwhelming for many teachers. In addition, the reform of the administration, inspection and payment systems added to the state of flux in Irish education at the time.

\section{Conclusion}

The pace of educational change can be slow and sluggish at times but it also comprises epochs of concentrated and comprehensive renewal. Advance, consolidation, encrustation, revitalisation are all patterns which the history of education reveals. (Coolahan, 1987, p. 4)

The period 1898-1922 was such an era of 'concentrated and comprehensive renewal' regarding the programme of the national schools. The Revised Programme (1900) was progressive and enlightened in its philosophy and sought to redress the imbalance within primary education. In fact, the language and content of the Revised Programme is re-echoed in many later curricula in Ireland, including the New Curriculum in 1971 and in the current Primary School Curriculum (Department of Education and Science [DES], 1999), coincidentally called the 'Revised Curriculum'. It was perhaps this progressive nature, certainly more revolutionary than evolutionary in its approach, that was one of the major challenges to its implementation. 
While conceptually well devised, the Revised Programme lacked a strategic implementation policy tempered to the societal and educational context of the day, and failed to provide an appropriate support infrastructure to ensure successful implementation. The school programme exists within the wider political, social, religious, economic, cultural and educational milieu and any proposed changes will be tempered by these wider influences. Modern theorists on educational change, a discipline that had not developed in the period under review, argue that curriculum change is complex and must be viewed as an evolutionary process, where gradual modernisation proves more steadfast than revolutionary transformations (Sarason, 1990; Fullan, 1993; Hargreaves, 1994; Sugrue, 1997). In short, it was the right programme, but not for the societal and educational context of Ireland in 1900.

Many of these perennial problems and challenges regarding curriculum implementation remain familiar to us one hundred years later at the start of the twentyfirst century. As the historical perspective teaches us, curriculum development is a continuum, of which devising the curriculum is but an initial step. Of far greater importance and complexity is its implementation, which will not be successful without concerted action and support at national and individual level. The neglect of planning and providing for the implementation of educational policy in Ireland has been a recurring theme throughout the last century (Coolahan, 1995). It is encouraging that many of the challenges that militated against the successful implementation of the Revised Programme of Instruction (1900) have been addressed in the implementation of the current curriculum, introduced in 1999 (DES, 1999). These include greater consultation and a partnership approach with the stakeholders involved in the education system in devising the curriculum, greater investment in the education system, and ensuring a phased and supported systematic plan for implementation. Moreover, the current curriculum built on its predecessor rather than involving a radical change in direction, and was accompanied by supports to assist implementation at an individual school level, such as the Primary Curriculum Support Programme and the School Development Planning Service.

Despite such provisions, it is apparent from recent reviews of implementation that realising curricular change is still problematic in the twenty-first century (DES, 2005; National Council for Curriculum and Assessment, 2005). Effecting curricular change is a long and complex process that requires a cycle of careful planning, observation, assessment and revision in the light of experience. It is hoped that insights from the past will inform contemporary curriculum planning and implementation into the future to ensure that educational policy translates into effective classroom practice.

\section{References}

Abstracts of the Board's [Commissioners of National Education] Proceedings, 10 ${ }^{\text {th }}$ April 1900 (1900) National Library of Ireland, LO 2351.

Commissioners of National Education (1897) $63^{\text {rd }}$ report of the Commissioners of National Education in Ireland for 1896-97 (Dublin, Alexander Thom and Co.) [C. 8600]. 
Commissioners of National Education (1900) $66^{\text {th }}$ report of the Commissioners of National Education in Ireland for 1899-1900, Appendix, Section II (M): Census returns as to illiteracy (Dublin, Alexander Thom and Co.) [Cd. 287].

Commissioners of National Education (1902a) $67^{\text {th }}$ report of the Commissioners of National Education in Ireland for 1900, Appendix, Section 1: Mr. Downing, Chief Inspector (Dublin, Alexander Thom and Co.) [Cd. 954].

Commissioners of National Education (1902b) $67^{\text {th }}$ report of the Commissioners of National Education in Ireland for 1900, Appendix, Section II (F): Revised programme of instruction in national schools (Dublin, Alexander Thom and Co.) [Cd. 872].

Commissioners of National Education (1905) $71^{\text {st }}$ report of the Commissioners of National Education in Ireland for 1904 (Dublin, Alexander Thom and Co.) [Cd. 2567].

Commissioners of National Education (1906) $72^{\text {nd }}$ report of the Commissioners of National Education in Ireland for 1905-1906, Appendix, Section II (K) (Dublin, Alexander Thom and Co.), 191-212 [Cd. 3185].

Commissioners of National Education (1921) $86^{\text {th }}$ report of the Commissioners of National Education in Ireland for 1919-1920 (Dublin, Alexander Thom and Co.) [Cmd 1476].

Commission on Manual and Practical Instruction in Primary Schools under the Board of National Education in Ireland (1898a) Final report 1898 (Dublin, Alexander Thom and Co.) [C. 8923].

Commission on Manual and Practical Instruction (1898b) Appendices to the reports of the commissioners (Dublin, Alexander Thom and Co.) [C. 8925].

Coolahan J. (1975) The origins of the Payment by Results policy in education and the experience of it in the national and intermediate schools in Ireland. Unpublished M.Ed thesis, Trinity College Dublin.

Coolahan, J. (1981) 'Education' in the training colleges - Carysfort 1877-1977: two centenary lectures (Blackrock, Our Lady of Mercy College), 20-52.

Coolahan, J. (1987) Introduction, in: A. Hyland, \& K. Milne Irish educational documents_Volume 1. Selection of extracts from documents relating to the history of Irish education from the earliest times to 1922 (Dublin, Church of Ireland College of Education), 1-22.

Coolahan, J. (Ed.) (1995) Issues and strategies in the implementation of educational policy-proceedings of a bicentenary conference (Education Department, National University of Ireland, Maynooth)

Coolahan, J. (2005) The schoolmaster in the new state, in: G. Fitzmaurice (Ed.) The world of Bryan MacMahon (Cork, Mercier Press), 163-192.

Dale, F. H. (1904) Report of Mr. F. H. Dale, His Majesty's Inspector of Schools, Board of Education, on primary education in Ireland (Dublin, Alexander Thom and Co.) [Cd. 1981].

Department of Education and Science (1999) Primary school curriculum (Dublin, The Stationery Office).

Department of Education and Science (2005) An evaluation of curriculum implementation in primary schools - English, mathematics and visual arts (Dublin, The Stationery Office).

Downing, E. and Purser, A. (1900) Observations on the new school programme 16/07/1900, in: Vice-Regal Committee of Inquiry into Primary Education (Ireland) (1913c) Appendix to the Second Report of the Committee - Appendix XXVII, 489-490 [Cd. 7229].

Fullan, M. (1993) Change forces: probing the depths of educational reform (London, Falmer Press).

Hargreaves, A. (1994) Changing teachers, changing times: teachers' work and culture in the postmodern age (London, Cassell).

Heller, W. M. (1902) The introduction of practical instruction into Irish national schools, Irish School Monthly - A Magazine of Practical School Work, 3(2), October, 35-40.

Hyland, A. (1973) Educational innovation-A case study. An analysis of the Revised Programme of 1900 for national schools in Ireland. Unpublished M.Ed. thesis, Trinity College Dublin.

Hyland, A. (1987) The process of curriculum change in the Irish national school system, Irish Educational Studies, 6(2), 17-38. 
Irish National Teachers' Organisation (1901) Congress programme for 1901-The thirty-fourth annual congress, Royal University Buildings Dublin (Dublin, Oraham).

Irish School Monthly - A Magazine of Practical School Work (1900) Our aims and objectives, 1(1), September, 3-4.

Irish Teachers' fournal (1900) National education - the new programme from the teachers' point of view, 34(43), 27 October, 4-6.

Irish Teachers' fournal (1902) The new system, 36(6), 8 February, 3-4.

National Council for Curriculum and Assessment (2005) Primary curriculum review: Phase 1-final report (Dublin, National Council for Curriculum and Assessment).

Nic Ghiolla Phádraig, M. (1990) Childhood as a social phenomenon-national report Ireland. European Centre for Social Welfare Policy and Research. Eurosocial Report 36/8 (Vienna, European Centre for Social Welfare Policy and Research).

Ó Buachalla, S. (1988) Education policy in twentieth century Ireland (Dublin, Wolfhound Press).

O'Connor, M. (1987) The development of infant education in Ireland 1900-1971, An Múinteoir, 1(3), Summer, $15-17$.

O'Donoghue, T. (2000) Bilingual education In Ireland 1904-1922-the case of the Bilingual Programme of Instruction. Centre for Irish Studies Monograph Series, 1 (Perth, Murdoch University).

Royal Commission of Inquiry into Primary Education (Ireland) (1870) Conclusions and recommendations contained in the general report, Vol. 1, Part X [C-6].

Sarason, S. (1990) The predictable failure of educational reform (San Francisco, Jossey-Bass).

Selleck, R. (1968) The New Education - The English background 1870-1914 (Melbourne, Sir Isaac Pitman and Sons Ltd).

Starkie, W. (1911) The history of Irish primary and secondary education during the last decade - an inaugural address (Belfast, Queen's University).

Sugrue, C. (1997) Complexities of teaching: child-centred perspectives (London, Falmer Press).

The Freeman's fournal (1900) Meeting of national teachers at Tramore - The new rules. 7 September.

Vice-Regal Committee of Inquiry into Primary Education (Ireland) (1913a) Final report of the Committee [Cd. 7235].

Vice-Regal Committee of Inquiry into Primary Education (Ireland) (1913b) Appendix to the First Report of the Committee, Appendix 1: Growth of the System of National Education [Cd. 6829].

Vice-Regal Committee of Inquiry into Primary Education (Ireland) (1913c) Appendix to the second report of the committee, Appendix 28: Report of the Board of National Education, made for the information of his Excellency the Lord Lieutenant, in reference to the recommendations of the Commission on Manual and Practical Instruction, 490-495 [Cd. 7229].

Walsh, T. (2006) A critical analysis of curricular policy in Irish primary schools, 1897-1990. Unpublished Ph.D thesis, National University of Ireland, Maynooth. 